AJHSE Vol: 2 (2): 12-24 2021

DOI: 10.52417/ajhse.v2i2.151

Accepted Date: Sept.30, 2021

(C) 2021. CC License 4.0

www.ajhse.org

\title{
ASSESSMENT OF FASCIOLA GIGANTICA INFECTION IN THE LIVER OF CATTLE SLAUGHTERED IN IKPOBA/OKHA AREA COUNCIL, EDO STATE, NIGERIA
}

\author{
${ }^{* 1}$ Edo-Taiwo, O. \& ${ }^{2}$ Ikpoboyuwa, O.V. \\ ${ }^{*}$ I\&2 Department of Animal and Environmental Biology, Faculty of Life Sciences, University of Benin, Benin City, Nigeria \\ *Corresponding Author's E-mail: omoyemwen.edo-taiwo@ uniben.edu Phone: +2348023579794
}

\begin{abstract}
7 his study investigated the prevalence and intensity of Fasciola gigantica infection in the liver of cattle slaughtered in three abattoirs located in Ikpoba/Okha Local Government Area of Edo State, Nigeria. It also estimated the economic implications of the condemned liver. A total of 17,325 cattle were examined in the three abattoirs over a period of 252 days (approximately 69 cattle/day) spanning over the wet and dry seasons; 1,683 cattle were infected with an overall prevalence of 9.71\%. In Abattoir A, 11774 cattle were examined with 1069 (9.08\%) prevalence. In Abattoirs B and C, 4352 and 1199 cattle, respectively, were examined and 563 (12.94\%) and $51(4.25 \%)$ were respectively infected. From the three abattoirs, $155(0.89 \%)$ livers were considered unfit for human consumption due to F. gigantica infection. For the wet season, 1062 (10.89\%) cattle livers were infected while 621 (8.20\%) were infected during the dry season. The mean intensity of infection during the wet season was 37.80 and 30.42 during the dry season. The financial loss due to infected liver condemnation was at N803,160 (1,947.050USD) showing that liver condemnation arising from F. gigantica infection is a major cause of financial loss to cattle farmers and dealers. There is, therefore, need for adequate veterinary inspections for early detection and treatment of the disease. There should be more meat inspection, especially in private/individual abattoirs.
\end{abstract}

Keywords: Cattle, liver, Fasciola gigantica, prevalence, economic loss

LICENSE: This article by African Journal of Health, Safety and Environment (AJHSE)is licensed and published under the Creative Commons Attribution License 4.0 International License, which permits unrestricted use, distribution, and reproduction in any medium, provided this article is duly cited.

COPYRIGHT: The Author(s) completely retain the copyright of this published article.

OPEN ACCESS: The Author(s) approves that this article remains permanently online in the open access (OA) model

QA:This Article is published in line with “COPE (Committee on Publication Ethics) and PIE (Publication Integrity \& Ethics)". 


\section{INTRODUCTION}

Fasciola gigantica (the giant liver fluke) is an important plant-borne trematode found mainly in sheep and cattle. The parasite resides in the bile ducts and gall bladder of mammals, especially ruminants and occasionally man (Biu et al., 2006; Otubanjo, 2013). Fasciola gigantica is mainly found in tropical areas (Soliman et al., 2008). Animals become infected while grazing, and they consume the metacercariae of the Fasciola parasite along with aquatic vegetation (Nyindo and Lukambagire, 2015). Fasciola gigantica causes tropical fascioliasis and it is regarded as one of the most important single platyhelminth infections of ruminants in Asia and Africa. The prevalence of fascioliasis in many parts of Africa has been determined mainly at slaughter (Phiri et al., 2005b). Infection of the parasite depends largely on the aquatic snail intermediate host (Lymnaea natalensis) ecology.

Over the years, investigations have been carried out on F. gigantica infection in the world including Nigeria and this has led to improvement in the control measures and decrease in production losses. In Nsukka urban abattoir, Ngwu et al. (2004) reported $10 \%$ prevalence of $F$. gigantica infection in the liver of slaughtered cattle. Ekwunife and Eneanya (2006) investigated the infection prevalence of $F$. gigantica in cattle slaughtered in three abattoirs at Onitsha area of Anambra State, Nigeria and reported a prevalence of $0.51 \%$. The respective prevalence recorded from the abattoirs was: Nkwor-Ogidi, 7.0\%; Oye Olisa, 7.7\%; and Onitsha main market, 13.4\%. Among the infected livers, $46.4 \%$ showed medium worm burden, while $38 \%$ and $17.7 \%$ respectively, showed heavy and light worm burdens. The highest number of flukes was 88 and the lowest was 3 per infected liver. In Edo State, Odigie and Odigie (2013) carried out a histochemical techniques-based study on fascioliosis in cattle slaughtered in abattoirs located in three local government areas. A total of 540 cattle were examined with a prevalence of $11.5 \%$. The infected liver showed increase in size with thick capsule, haemorrhagic patches and necrotic foci. Adult and young flukes were recovered from the bile ducts of 62 livers of the examined cattle. Liver cirrhosis was observed in only three cattle liver. The authors noted that differences in feed and water quality in the abattoirs possibly influenced the prevalence of Fasciola disease. A retrospective and prospective study of the predisposing factors and economic implication of fascioliasis in trade cattle slaughtered at abattoir in north-central Nigeria was conducted by Yatswako et al. (2017). The study was carried out between January, 2004 and December, 2014 in five municipal abattoirs in Niger State, by liver examination. From the retrospective study, a total of 3,292,634 trade cattle were slaughtered and examined within the years. Of the slaughtered cattle, 47,931 (1.46\%) had their livers condemned due to Fasciola infection. The economic loss due to liver condemnation was $\$ 766,896$.0. From the retrospective study, it was observed that breed and age significantly influenced fasciolosis. In another study to determine the prevalence of Fasciola species among ruminant animals, Isah et al. (2019) recorded $40.5 \%$ prevalence from stool samples of ruminants examined. Prevalence was highest in cattle (45.7\%) followed by sheep (39.1\%) while the least was in goats $(35.01 \%)$. The seasonal record showed that the highest prevalence (58.4\%) was observed during the late rainy season (August to October), followed by the early rainy season (47.2\%) and least was in late dry season (20.1\%). Other studies on $F$. gigantica infection in Nigeria include Adedokun et al. (2008), Abraham and Jude (2014), Ejeh et al. (2015), Afolabi and Olususi (2016) and Okoh et al. (2016) among others. 
Although a lot of investigations have been done on Fasciola infection in the liver of slaughtered cattle at abattoirs, there is need for continuous monitoring of the infection in cattle slaughtered and consumed by the populace, especially with respect to the economic implications of liver condemnation. The occurrence of $F$. gigantica in the liver of a cow leads to its condemnation especially if the liver is heavily infected, which makes it unhealthy for consumption.

The aim of this study is to investigate the prevalence and infection intensity of $F$. gigantica in cattle slaughtered at some selected abattoirs in Ikpoba/Okha Local Government Area of Edo State, Nigeria, as well as estimates the economic loss arising from condemnation of infected liver of the slaughtered cattle.

\section{MATERIALS AND METHODS}

The study was conducted in three abattoirs designated as 'A' $\left(6^{\circ} 21^{\prime} 13^{\prime \prime} \mathrm{N}\right.$ and $\left.5^{\circ} 38^{\prime} 33^{\prime \prime} \mathrm{E}\right)$, 'B' $\left(6^{\circ} 21^{\prime} 18^{\prime \prime} \mathrm{N}\right.$ and $\left.5^{\circ} 38^{\prime} 39^{\prime \prime} \mathrm{E}\right)$ and 'C' (6 $6^{\circ} 21^{\prime} 17^{\prime \prime} \mathrm{N}$ and 5 $\left.38^{\prime} 41^{\prime \prime} \mathrm{E}\right)$ at Ikpoba Hill, Ikpoba/Okha LGA, Edo State, Nigeria (Fig. 1) for 252 days covering both the wet (April to October) and dry season (November to March). The livers of cattle slaughtered in these abattoirs were examined for $F$. gigantica infection. A premortem examination (checking for skin swellings, if the cattle looked emaciated or has dislocated arm/leg) was carried out on the cattle before slaughtering to determine if the cattle were in good health, if otherwise, if the cattle were treated.

Post mortem examination was carried out after slaughter for Fasciola infection, abcess, tubercolosis and hepatitis. To determine Fasciola parasite infection, the liver was slit open vertically and examined. Parasites were isolated from the infected liver with the aid of forceps, counted and stored in well labeled bottles containing $0.72 \%$ saline solution. They were thereafter taken to the laboratory and processed for parasitological procedures (Aisien, 2018). The parasites were flattened between two microscope slides and fixed with 5\% formal-saline for about 30 minutes. They were then recovered and preserved with the same fixative. The preserved parasites were washed in several changes of tap water for four hours. They were stained with a weak solution of acetocamine and then dehydrated in increasing alcohol series (50:70:90:100\%). The dehydrated specimens were cleared first in 50/50 alcohol/xylene mixture (v/v) before clearing in absolute xylene. Permanent mount was made in Canada balsam.

Prevalence and mean intensity of parasitic infection were calculated. The Chi-square goodness of fit test was performed to test for significant difference between variables. Economic loss was estimated according to the protocol of Mwabonimana et al. (2009). This was done by multiplying the average weight of liver by the cost of liver/kg (at the time of survey) with the number of cattle liver infected and termed unfit for human consumption; while the percentage economic loss was calculated by dividing the estimated cost of liver condemned by the estimated cost of all the liver examined and multiplied by $100 \%$. US Dollar equivalent of Naira was calculated based on the Central Bank of Nigeria's official exchange rate as at February, 2021 (N390=1 USD). 


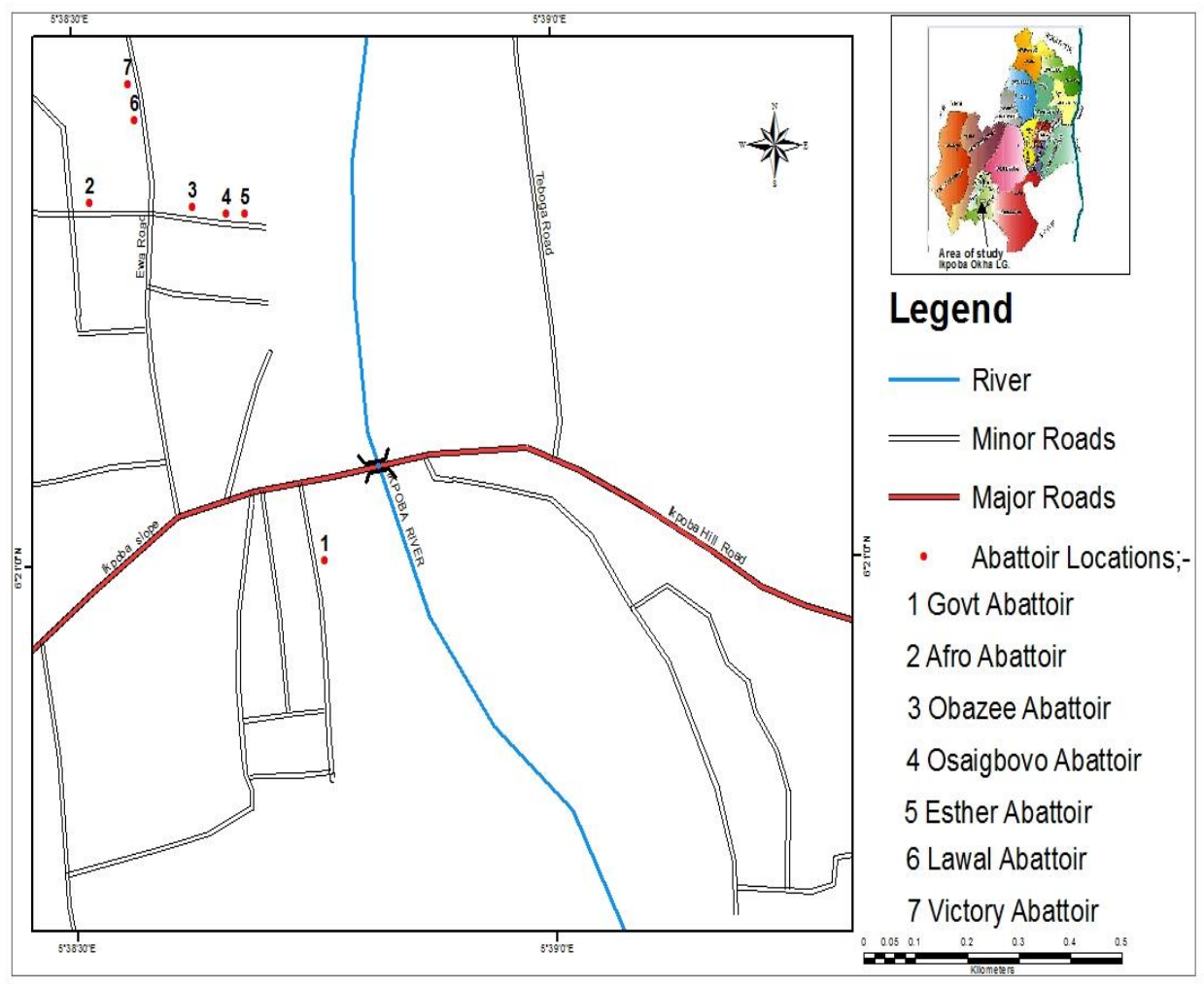

Figure 1: Map of study area showing the different sampled abattoirs in Ikpoba-Hill, Ikpoba/Okha LGA, Edo State, Nigeria

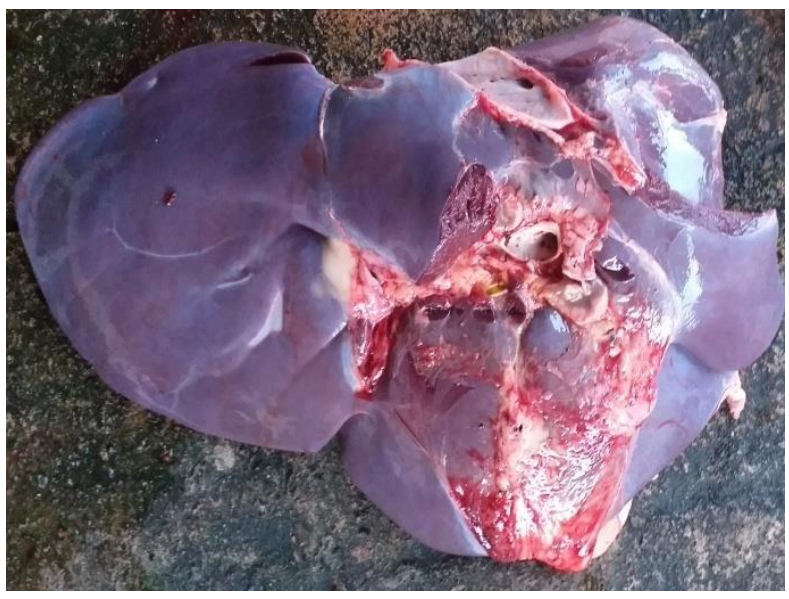

Figure 2: A healthy liver 


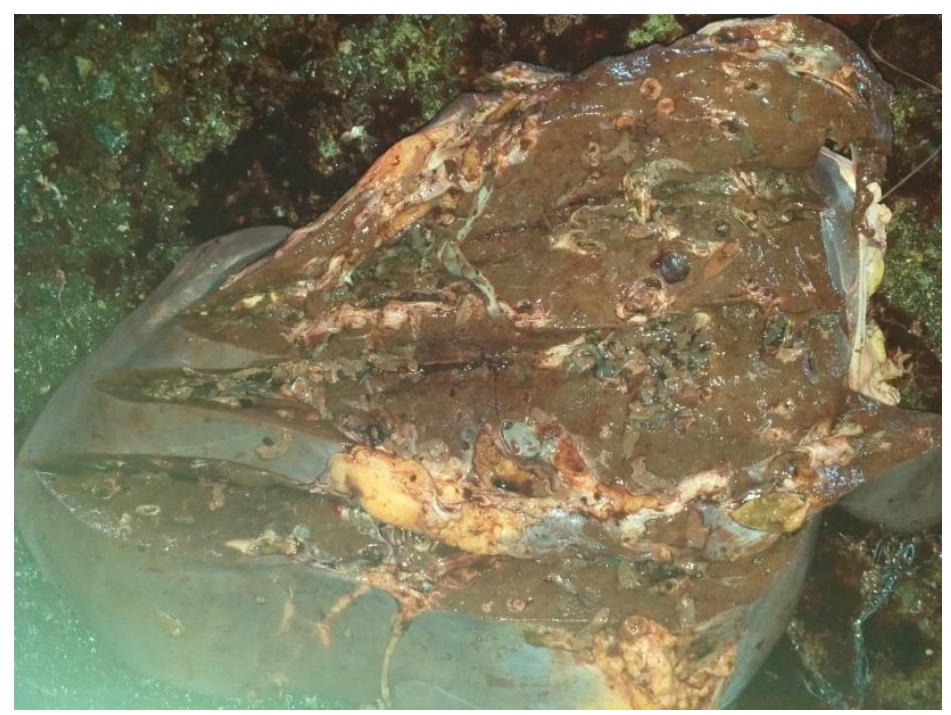

Figure 3: Infected liver with $F$. gigantica

\section{RESULTS}

A total of 17,325 whole livers were examined of which $1,683(9.71 \%)$ were infected with $F$. gigantica. The number of parasites recovered from the infected liver was 59,033 with an overall mean intensity of 35.08 parasites/infected liver. The intensity of parasitic infection recorded in the livers examined at Abattoir A, B and C were 33.44, 37.64 and 40.96 parasites/infected host, respectively (Table 1$)$. These differences was however not significant $(\mathrm{P}>0.05)$. In Abattoir A, 11774 cattle liver were examined and 1069 (9.08\%) were infected; in Abattoirs B and C, 4352 and 1199 liver were respectively examined; 563 (12.94\%) and 51 (4.25\%) were respectively infected (Table 2). The differences recorded were not statistically significant $(\mathrm{P}>0.05)$. The average cattle liver examined daily in the abattoirs were: Abattoir A, 47; B, 17 and C, 5 livers/day. 
Table 1: Overall prevalence and mean intensity of Fasciola gigantica infection

\begin{tabular}{|c|c|c|c|c|c|}
\hline Abattoir & $\begin{array}{c}\text { Number of } \\
\text { livers } \\
\text { examined }\end{array}$ & $\begin{array}{l}\text { Number of } \\
\text { liver infected }\end{array}$ & Prevalence (\%) & $\begin{array}{c}\text { Number of } \\
\text { parasites }\end{array}$ & Mean intensity \\
\hline A & 11774 & 1069 & 9.07 & 35751 & 33.44 \\
\hline B & 4352 & 563 & 12.94 & 21193 & 37.64 \\
\hline $\mathrm{C}$ & 1199 & 51 & 4.25 & 2089 & 40.96 \\
\hline Total & 17325 & 1683 & 9.71 & 59033 & 35.08 \\
\hline$X^{2}$ & & & 4.692 & & 0.875 \\
\hline DF & & & 2 & & 2 \\
\hline P-VALUE & & & 0.096 & & 0.646 \\
\hline SIG* & & & $\mathrm{P}>0.05$ & & $\mathrm{P}>0.05$ \\
\hline
\end{tabular}

Note: $\mathrm{P}>0.05=$ No significant difference

Table 2: Monthly Prevalence of Fasciola gigantica infection in liver of cattle slaughtered in some abattoirs at Ikpoba/Okha LGA, Edo State, Nigeria (February, 2020 - January 2021)

\begin{tabular}{lccccccccc}
\hline & \multicolumn{2}{c}{ Abattoir A } & \multicolumn{3}{c}{ Abattoir B } & \multicolumn{3}{c}{ Abattoir C } \\
\hline Month & $\begin{array}{l}\text { No. of } \\
\text { cattle } \\
\text { examined }\end{array}$ & $\begin{array}{l}\text { No. } \\
\text { infected }\end{array}$ & $\begin{array}{l}\text { Prev. } \\
(\%)\end{array}$ & $\begin{array}{l}\text { No. of } \\
\text { cattle } \\
\text { examined }\end{array}$ & $\begin{array}{l}\text { No. } \\
\text { infected }\end{array}$ & $\begin{array}{l}\text { Prev. } \\
(\%)\end{array}$ & $\begin{array}{l}\text { No. of } \\
\text { cattle } \\
\text { examined }\end{array}$ & $\begin{array}{l}\text { No. } \\
\text { infected }\end{array}$ & $\begin{array}{l}\text { Prev. } \\
(\%)\end{array}$ \\
\hline February & 801 & 57 & 7.12 & 495 & 36 & 7.27 & 86 & 05 & 5.81 \\
March & 1011 & 86 & 8.51 & 615 & 54 & 8.79 & 93 & 07 & 7.53 \\
April & 608 & 80 & 13.16 & 360 & 14 & 3.89 & 67 & 03 & 4.48 \\
May & 621 & 72 & 11.59 & 416 & 24 & 5.77 & 78 & 03 & 3.85 \\
June & 1039 & 65 & 6.26 & 309 & 36 & 11.65 & 106 & 01 & 0.94 \\
July & 1163 & 123 & 10.57 & 313 & 28 & 8.95 & 116 & 02 & 1.72 \\
August & 1184 & 125 & 10.56 & 307 & 56 & 18.24 & 109 & 06 & 5.5 \\
September & 1085 & 118 & 10.88 & 299 & 100 & 33.44 & 109 & 10 & 9.17 \\
October & 1064 & 103 & 9.68 & 299 & 88 & 29.43 & 104 & 05 & 4.81 \\
November & 1079 & 87 & 7.32 & 318 & 60 & 18.87 & 105 & 03 & 2.86 \\
December & 1180 & 94 & 7.97 & 335 & 37 & 11.04 & 116 & 04 & 3.45 \\
January & 939 & 59 & 6.28 & 286 & 30 & 10.49 & 110 & 02 & 1.82 \\
TOTAL & $\mathbf{1 1 7 7 4}$ & $\mathbf{1 0 6 9}$ & $\mathbf{9 . 0 8}$ & $\mathbf{4 3 5 2}$ & $\mathbf{5 6 3}$ & $\mathbf{1 2 . 9 4}$ & $\mathbf{1 1 9 9}$ & $\mathbf{5 1}$ & $\mathbf{4 . 2 5}$ \\
\hline
\end{tabular}


Of the 17,325-liver examined, $15642(90.29 \%)$ were not infected with $F$. gigantica parasite while $155(0.89 \%)$ were infected and considered unfit for human consumption (Table 3). There was a high significant difference (P<0.001) between the number of cattle slaughtered in the three abattoirs. High significant difference was also recorded between the healthy liver and the livers considered unfit for consumption in these abattoirs. The highest prevalence (95.75\%) of healthy liver was recorded in Abattoir C followed by Abattoir A (90.92\%) and B (87.06\%). Abattoir B had the highest prevalence (1.24\%) of unfit liver for consumption followed by Abattoir A $(0.80 \%)$ while the least $(0.58 \%)$ was recorded in Abattoir C.

Table 3: Overall prevalence of Healthy and condemned liver due to Fasciola gigantica infection in the three abattoirs

\begin{tabular}{lccccc}
\hline Abattoir & $\begin{array}{c}\text { No. of liver } \\
\text { examined }\end{array}$ & $\begin{array}{c}\text { No. of Healthy } \\
\text { liver }\end{array}$ & $\begin{array}{c}\text { Prevalence } \\
(\%)\end{array}$ & $\begin{array}{c}\text { No. of liver } \\
\text { unfit for } \\
\text { consumption }\end{array}$ & $\begin{array}{c}\text { Prevalence } \\
(\%)\end{array}$ \\
\hline A & 11774 & 10705 & 90.92 & 94 & 0.80 \\
B & 4352 & 3789 & 87.06 & 54 & 1.24 \\
C & 1199 & 1148 & 95.75 & 07 & 0.58 \\
Total & 17325 & 15642 & 90.29 & 155 & 0.89 \\
$\mathrm{X}^{2}$ & 10208.261 & 850.878 & 4.000 & 73.406 & 0.000 \\
DF & 2 & 2 & 2 & 2 & 2 \\
P-VALUE & 0.000 & 0.000 & 0.135 & 0.000 & 1.000 \\
SIG* & $\mathrm{P}<0.001$ & $\mathrm{P}<0.001$ & $\mathrm{P}>0.05$ & $\mathrm{P}<0.001$ & $\mathrm{P}>0.05$ \\
\hline
\end{tabular}

Note: $\mathrm{P}>0.05=$ No significant difference, $\mathrm{P}<0.001=$ High significant difference

With respect to season, 9756 livers were examined during the wet season (April - October) while 7569 were examined during the dry (November - March). A total of 1062 (10.89\%) cattle liver were infected during the wet season while $621(8.20 \%)$ were infected during the dry season. The overall mean intensity during the wet and dry season was 37.80 and 30.42, respectively. The highest seasonal prevalence of parasitic infection was recorded in Abattoir B (wet, $15.02 \%$; dry, $10.59 \%$ ), followed by A (wet $10.14 \%$; dry, $7.64 \%$ ) while the least was in C (wet, $4.35 \%$; dry, $4.12 \%$ ) as shown in Table 4. Abattoir B also had the highest parasite load of 41.30 parasites/infected host during the wet season (dry season, 31.81). However, the highest parasite burden during the dry season (51.81) was recorded in Abattoir C (wet, 33.37). The infection intensities recorded in Abattoir A during the wet and dry seasons were 36.22 and 28.46 parasites/infected host, respectively. Significant differences were observed between the wet season prevalence and dry season mean intensity in the three abattoirs $(\mathrm{P}<0.05)$. However, the wet season intensity and dry season prevalence differences were not significant in these abattoirs $(\mathrm{P}>0.05)$. 
Table 4: Overall seasonal prevalence of Fasciola gigantica infection in cattle slaughtered in the three abattoirs

\begin{tabular}{|c|c|c|c|c|c|c|c|c|c|c|}
\hline & \multicolumn{5}{|c|}{ Wet season } & \multicolumn{5}{|c|}{ Dry season } \\
\hline $\begin{array}{l}\text { Abatt } \\
\text { oir }\end{array}$ & $\begin{array}{l}\text { No. } \\
\text { examin } \\
\text { ed }\end{array}$ & $\begin{array}{l}\text { No. } \\
\text { infect } \\
\text { ed }\end{array}$ & $\begin{array}{l}\text { Prevale } \\
\text { nce }(\%)\end{array}$ & $\begin{array}{l}\text { No. } \\
\text { of } \\
\text { parasi } \\
\text { te }\end{array}$ & $\mathrm{MI} \pm \mathrm{SD}$ & $\begin{array}{l}\text { No. } \\
\text { examin } \\
\text { ed }\end{array}$ & $\begin{array}{l}\text { No. } \\
\text { infect } \\
\text { ed }\end{array}$ & $\begin{array}{l}\text { Prevale } \\
\text { nce }(\%)\end{array}$ & $\begin{array}{l}\text { No. } \\
\text { of } \\
\text { parasi } \\
\text { te }\end{array}$ & $\mathrm{MI} \pm \mathrm{SD}$ \\
\hline A & 6764 & 686 & 10.14 & $\begin{array}{l}2485 \\
2\end{array}$ & $\begin{array}{l}36.22 \pm 47 \\
.75\end{array}$ & 5010 & 383 & 7.64 & $\begin{array}{l}1089 \\
9\end{array}$ & $\begin{array}{l}28.46 \pm 39 \\
.60\end{array}$ \\
\hline B & 2303 & 346 & 15.02 & $\begin{array}{l}1429 \\
1\end{array}$ & $\begin{array}{l}41.30 \pm 63 \\
.00\end{array}$ & 2049 & 217 & 10.59 & 6902 & $\begin{array}{l}31.81 \pm 46 \\
.43\end{array}$ \\
\hline $\mathrm{C}$ & 689 & 30 & 4.35 & 1001 & $\begin{array}{l}33.37 \pm 30 \\
.81\end{array}$ & 510 & 21 & 4.12 & 1088 & $\begin{array}{l}51.81 \pm 78 \\
.79\end{array}$ \\
\hline Total & 9756 & 1062 & 10.89 & $\begin{array}{l}4014 \\
4\end{array}$ & $\begin{array}{l}37.80 \pm 47 \\
.18\end{array}$ & 7569 & 621 & 8.20 & $\begin{array}{l}1888 \\
9\end{array}$ & $\begin{array}{l}30.42 \pm 35 \\
.63\end{array}$ \\
\hline$X^{2}$ & & & 6.276 & & 0.891 & & & 3.217 & & 8.857 \\
\hline DF & & & 2 & & 2 & & & 2 & & 2 \\
\hline $\begin{array}{l}\mathrm{P}- \\
\text { value }\end{array}$ & & & 0.043 & & 0.641 & & & 0.200 & & 0.012 \\
\hline Sig. & & & $\mathrm{P}<0.05$ & & $\mathrm{P}>0.05$ & & & $\mathrm{P}>0.05$ & & $\mathrm{P}<0.05$ \\
\hline
\end{tabular}

MI, Mean intensity

The monthly economic loss due to liver condemnation arising from $F$. gigantica infection in slaughtered cattle in the three abattoirs during the study period is presented in Table 5. A total of N803,160 (1,947.05USD) was lost to $F$. gigantica infection in the three abattoirs. The percentage economic loss for the study period was $0.92 \%$. The highest financial loss of N479,320 (1,161.99USD) was recorded in Abattoir A. This was followed by Abattoir B, N286,120 (693.62USD) and Abattoir C, N37,720 (91.44USD). 
Table 4: Economic loss due Fasciola gigantica infection in cattle

\begin{tabular}{|c|c|c|c|c|c|c|c|}
\hline \multicolumn{4}{|c|}{ Abattoir A } & \multicolumn{2}{|c|}{ Abattoir B } & \multicolumn{2}{|c|}{ Abattoir C } \\
\hline Month & $\begin{array}{l}\text { No. of liver } \\
\text { condemned }\end{array}$ & $\begin{array}{l}\text { Cost of } \\
\text { liver/Kg } \\
\text { AV. } \\
\text { WT=4.6 }\end{array}$ & $\begin{array}{l}\text { Estimated } \\
\text { loss } \\
\text { (Naira) }\end{array}$ & $\begin{array}{l}\text { No. of liver } \\
\text { condemned }\end{array}$ & $\begin{array}{l}\text { Estimated } \\
\text { loss } \\
\text { (Naira) }\end{array}$ & $\begin{array}{l}\text { No. of liver } \\
\text { condemned }\end{array}$ & $\begin{array}{l}\text { Estimated } \\
\text { loss } \\
\text { (Naira) }\end{array}$ \\
\hline Feb. & 08 & 700 & 25760 & 04 & 12880 & 01 & 3220 \\
\hline Mar. & 15 & 1000 & 69000 & 05 & 23000 & - & - \\
\hline Apr. & 11 & 1000 & 50600 & 01 & 4600 & - & - \\
\hline May & 08 & 1200 & 44160 & 03 & 16560 & - & - \\
\hline Jun. & 03 & 1200 & 16560 & 03 & 16560 & - & - \\
\hline Jul. & 14 & 1200 & 77280 & 01 & 5520 & - & - \\
\hline Aug. & 09 & 1200 & 49680 & 06 & 33120 & 01 & 5520 \\
\hline Sep. & 11 & 1200 & 60720 & 09 & 49680 & 02 & 11040 \\
\hline Oct. & 04 & 1200 & 22080 & 14 & 77280 & 02 & 11040 \\
\hline Nov. & 08 & 1200 & 44160 & 06 & 33120 & - & - \\
\hline Dec. & 02 & 1500 & 13800 & 02 & 13800 & 01 & 6900 \\
\hline Jan. & 01 & 1200 & 5520 & - & - & - & - \\
\hline Total & 94 & & 479320 & 54 & 286120 & 07 & 37720 \\
\hline
\end{tabular}

\section{DISCUSSION}

The cattle slaughtered in the abattoirs investigated were trade cattle brought in from neighbouring countries (Chad and Niger) and from northern Nigeria (Sokoto, Kano and Zaria). Basically, two types of cattle were slaughtered in these abattoirs: the "groundnut" and the "bush" cattle. The "groundnut cattle" are so-called because they are fed with groundnut; they are always reared and fed in ranches hence they are not exposed to parasitic infection from external source unlike the "bush cattle" which are reared in the bush and feed on vegetation. The bush cattle wander about in search of food and water. This nomadic wandering predisposes them to larval stages of parasites, especially the metacercariae of $F$. gigantica, which they consume along with grass while grazing.

Fasciola gigantica infection was recorded throughout the period of survey. The overall prevalence of $F$. gigantica recorded in this study was high when compared to other reports. Oladele-Bukola and Odetokun (2014) reported a prevalence of $2.31 \%$ (with annual infection rate of $1.57 \%$ to $5.68 \%$ and a mean intensity of 3.7 parasites/infected host) during the retrospective and perspective analyses of bovine fasciolosis at Ibadan municipal abattoir. Afolabi and Olususi (2016) recorded 7.07\% prevalence of $F$. gigantica infection at Akure while a prevalence of $1.46 \%$ was reported by Yatswako and Alhaji (2017) in north-central Nigeria during a retrospective and prospective study. This is an indication that $F$. gigantica infection in cattle is on the increase. Cattle consume the metacercariae of 
$F$. gigantica along with vegetation during grazing. This indicates that there are still no adequate livestock management protocols despite the numerous outcries about the disease.

The prevalence in this study is low when compared with the account of Odigie and Odigie (2013) who reported a higher overall prevalence $(11.5 \%)$ of bovine fascioliasis in Edo State. This difference could be due to the histochemical techniques employed by these authors which probably detected more infection than the liver examination used in the present study. The report of higher fascioliasis prevalence by Odigie and Odigie (2013) is not an isolated case. Similarly, Okoh et al. (2016) reported higher prevalence of infection (34.3\%) from Lokoja, Kogi State. Liba et al. (2018) also reported a higher prevalence (13.67\%) of fasciolosis in cattle slaughtered in municipal abattoir in Maiduguri, Borno State. The higher prevalence recorded in these studies are due to the methods used in examination. A combination of bile and coprological examinations in addition to post-mortem examination of liver were employed and these combinations give a better audit of actual parasitic infections.

Although there were differences in the prevalence and mean intensity recorded among the three abattoirs in this study, these differences were however not significant $(\mathrm{P}>0.005)$. Abattoir A had the highest prevalence of healthy liver and the lowest prevalence liver unfit liver for consumption. These are indicative of adequate livestock management (uncontaminated feed and availability of clean water) in the various places where these cattle were kept.

A higher overall wet season prevalence (10.89\%) and intensity (37.80 parasites/infected host) of $F$. gigantica infection was recorded in the liver of cattle slaughtered in the abattoirs compared to dry season $(8.20 \%$; intensity, 30.42). This could be ascribed to the fact that more bush cattle were slaughtered during the wet season (personal communication). These are nomadic cattle that are exposed to parasitic infection especially when they graze in wet marshy areas where the cercariae-shedding snail intermediate host (Lymnaea spp.) of the parasite is abundant. When the cercariae are shed by the snail, they encyst on aquatic vegetation (metacercariae) which the cattle consume along with grass while grazing (Ukoli, 1984; Otubanjo, 2013). These findings are similar to the reports of Pfukenyi and Mukaratirwa (2004) in Zimbabwe who recorded a significantly higher $F$. gigantica infection in cattle in catchment areas of high rainfall than those from relatively low rainfall. In the same vein, Kuchai et al. (2011) reported higher prevalence of $F$. gigantica infection in cattle during the wet season in India. In Nigeria, Adedokun et al. (2008) similarly reported higher prevalence of $F$. gigantica in cattle during the wet season (52.3\%) than the dry season (21.8\%). A higher seasonal prevalence was also observed in Calabar by Abraham and Jude (2014); the authors reported $32.4 \%$ prevalence in cattle during the wet season and $19.9 \%$ during the dry season.

In contrast, Oladele-Bukola and Odetokun (2014) reported a slightly higher prevalence of fascioliasis during the dry season (2.58\%) than in the wet season (2.07\%) at Ibadan. Ejeh et al. (2015) also reported a similar trend of higher prevalence of $F$. gigantica in cattle during the dry season during a retrospective study at Makurdi.

The financial loss in the various abattoirs due to liver condemnation alone is substantial. A total of $803,160.00$ naira (1,947.05 USD) was lost accruing from 155 livers (713kg) condemned during the study period. Huge financial losses due to fascioliasis have also been reported by Oladele-Bukola and Odetokun (2014), Ejeh et al. (2015) and Yatswako and Alhaji (2017) respectively, from Ibadan, Makurdi and Niger State, which makes it urgent for cattle farmers to set better cattle management protocols that does not predispose cattle to the level of infection and financial loss to both herders and dealers in cattle. 


\section{CONCLUSION}

This study revealed that $F$. gigantica is still a prevalent parasitic infection of cattle. There is therefore need for urgent measures to be taken to reduce cattle infection with $F$. gigantica. These will include ranching and better access to veterinary services to reduce morbidity and the huge financial losses experienced by the cattle herders and dealers. Meat inspection especially in private/individual abattoirs should be enforced to prevent the sale and consumption of condemned liver.

\section{ACKNOWLEDGEMENTS}

We are grateful to Edo State Ministry of Agriculture for granting us the permission to carry out this study in the abattoirs and also to Dr. Endurance (veterinary doctor assigned to the abattoirs) for his support and cooperation during the abattoir investigations.

\section{CONFLICT OF INTEREST}

There was no conflict of interest. 


\section{REFERENCES}

Abraham, J.T. \& Jude, I.B. (2014). Fascioliasis in Cattle and Goat Slaughtered at Calabar Abattoirs. Journal of Biology, Agriculture and Healthcare. 4(18): 34-40. http://www.liste.org/.../15348.

Adedokun, A.O., Ayinmode, A.B. \& Fagbemi, O.B. (2008). Comparative study of three methods for detecting Fasciola infections in Nigerian cattle. Veterinarski Arhiv. 78(5): 411-416.

Afolabi, O. \& Olususi, F. (2016). The prevalence of fascioliasis among slaughtered cattle in $\quad$ Akure, Nigeria. Molecular pathogens. 7(1): 221-232. DOI: 10.5376/mp.2016.07.0001.

Aisien, M.S.O. (2018). Parasites of the Herpetofauna of Nigeria. Volume one Flatworms. Mindex Publishing Company Limited. 148pp.

Biu, A.A., Ahmed, M.I. \& Mshelia, S.S. (2006). Economic assessment of losses due to parasitic diseases common at the Maiduguri abattoir, Nigeria. African Scientist. 2(3): 143-145. http://www.klobex.org.

Ejah, E.F., Paul, B.T., Lawan, F.A., Lawal, J.R., Ejah, S. \& Hambali, U.I. (2015). Seasonal prevalence of bovine fascioliasis and its direct economic losses (del) due to liver condemnation at Makurdi Abattoirs north central Nigeria. Sokoto Journal of Veterinary Science. 13(2): 42-48. DOI: 10.4314/sokjvs. v13i2.7.

Ekwunife, C.A. \& Eneanya, C.I. (2006). Fascioliasis in Onitsha and Environs. Animal Research International. 3(2): 448-450. DOI: 10.4314/ari. v3i2.40768.

Kuchai, J.A., Chisthi, M.Z., Zaki, M.M., Ahmad, J., Rasool,M., Dar, S.A. and Tak, H. (2011). Epidemiology of helminth parasites in small ruminants of Ladakh, India. Online Journal of Animal and Feed Research. 1(5): 239-242. http://www.ojafr.ir.

Liba, J. W., Francis, M. \& Atsanda, N. N. (2018). Prevalence of fascioliasis in cattle slaughtered at Maiduguri Municipal Abattoir, Borno State, Nigeria. Nigerian Journal of Parasitology. 39(2): 242-247. http://dx.doi.org/10.4314/njpar.v39i2.22.

Mwabonimana, M-F., Kassuku, A.A., Ngowi, H.A., Mellau, L.S.B., Nonga, H.E. \& Karimuibo, E.D. (2009). Prevalence and economic significance of bovine fasciolosis in slaughtered cattle at Arusha abattoir, Tanzania. Tanzania Veterinary Journal. 26(2): 68-74. DOI: 10.4314/tvj. v2612.53804.

Nyindo, M. \& Lukambagire, A. (2015). Fascioliasis: An Ongoing Zoonotic Trematode Infection. Biomed Research International. http://dx.doi.org/10.1155/2015/786195.

Odigie, E. \& Odigie, J. (2013). Fascioliasis in cattle: a survey of abattoirs in Egor, Ikpoba/Okha and Oredo Local Government areas of Edo State, using histochemical techniques. International Journal of Basic, Applied and Innovative Research. 2(1):1-9.

Okoh, A.E.J., Shuaibu, G.A. \& Ofukwu, R.A. (2016). Cross sectional study of Bovine Fascioliasis at Lokoja Abattoir, Kogi State, Nigeria. Journal of Veterinary Science.11:80-86.

Oladele-Bukola, M.O. \& Odetokun, I.A. (2014). Prevalence of bovine fascioliasis at the Ibadan Municipal abattoir, Nigeria. African Journal of Food, Agriculture, Nutrition and Development. 14(4): 9055-9070.

Otubanjo, O. (2013). Parasites of Man and Animals. Concept Publications Limited. 648pp. 
Pfukenyi, D.M. \& Mukaratirwa, S. (2004). A retrospective study of the prevalence and seasonal variation of Fasciola gigantica in cattle slaughtered in the major abattoirs of Zimbabwe between 1990 and 1999. Onderstepoort Journal of Veterinary Research. 71: 181-187. DOI: 10.4102/ojvr.v71i3.258.

Phiri, I.K., Sikasunge, C.S. \& Monrad, J. (2005). Prevalence of fasciolosis in Zambian cattle observed at selected Abattoirs with emphasis on age, sex and origin. Journal of Veterinary Medicine. 52: 414-416.

Soliman, M.F.M. (2008). Epidemiological review of human and animal fascioliasis in Egypt. Journal of Infection in Developing Countries. 2(3): 182-189.

Ukoli, F.M.A. (1984). Introduction to Parasitology in Tropical Africa. John Wiley and Sons Limited. 464pp.

Yatswako, S. \& Alhaji, N.B. (2017). Survey of bovine fascioliasis burdens in trade cattle slaughtered at abattoirs in North-central Nigeria: The associated predisposing factors and economic implication. Parasite Epidemiology and Control. 2: 30-39. DOI: 10.1016/j.parepi.2017.02.001. 